FREDRIC JAMESON

Professor i litteratur ved Duke University

\title{
UTOPIENS POLITIK'
}

\begin{abstract}
THE POLITICS OF UTOPIA | The article discusses the continued relevance of utopia in the $21^{\text {st }}$ century as well as the general problems that arise from utopia as a literary and political phenomenon. Utopia - both as psychological "wishfulfilment" and as social construction - is involved in a contradictory relationship with the political. Utopia presupposes a "suspension" of politics, and hence utopias flourish in periods of social turmoil, but without political agency or direction. The function of utopia is first and foremost negative, in the sense that utopia does not offer a representation of a better future, but rather shows us that we are unable to imagine such a future because of the ideological closure of the system. Therefore, it will be impossible to develop an effective and critical political practice for the age of globalization without the resurrection of utopia.
\end{abstract}

KEYWORDS | ideology, utopia, politics, literature.

Utopien synes at stille os over for et af de sjældne fænomener, hvis begreb er uadskilleligt fra dets realitet, hvis ontologi er sammenfaldende med dets repræsentation. Har denne særegne størrelse stadig en social funktion? Hvis den ikke længere har det, ligger forklaringen muligvis i den bemærkelsesværdige historiske udsondring i to distinkte verdener, som kendetegner globaliseringen i dag. I den ene af disse verdener er det sociales opløsning så absolut - elendighed, fattigdom, arbejdsløshed, sult, uhumskhed, vold og død - at de utopiske tænkeres snørklede samfundsplaner bliver lige så frivole, som de er irrelevante. I den anden verden synes en hidtil ukendt velstand, computerbaseret produktion, et endeløst udvalg af kommercielle og kulturelle nydelser samt videnskabelige og medicinske opdagelser, der ikke lod sig forestille for et århundrede siden, at have gjort den utopiske fantasi og spekulation lige så kedsommelig og antikveret som de førteknologiske fortællinger om rumrejser.

Kun selve ordet overlever denne omfattende forældelse som et symbolsk tegn, om hvilket egentligt politiske kampe stadig hjælper os til at skelne mellem venstre og højre. På venstrefløjen er 'utopisk' således blevet et kodeord for socialisme eller kommunisme, mens det på højrefløjen er blevet synonymt med 'totalitarisme' - i praksis stalinisme. Disse to betydninger synes på visse måder at overlappe hinanden. Begge indebærer, at en politik, der stræber efter at forandre systemet radikalt, vil

I Først udgivet som “The Politics of Utopia”, New Left Review 25, 2004. Oversat af Bertel Nygaard. 
blive betegnet som utopisk - med den højreorienterede undertone, at systemet (i dag forstået som det frie marked) indgår i den menneskelige natur; at ethvert forsøg på at forandre det vil være ledsaget af vold; og at bestræbelser på at fastholde disse forandringer (imod den menneskelige natur) vil kræve et diktatur. Her er altså to praktisk-politiske spørgsmål på spil: på den ene side en venstrefløjskritik af den socialdemokratiske reformisme inden for systemet; på den anden side en fundamentalistisk opfattelse af det frie marked. Men hvorfor ikke ganske enkelt drøfte disse spørgsmål direkte og åbent, uden at gøre brug af dette tredje, tilsyneladende litterære, spørgsmål om utopi? Man kunne endda vende spørgsmålet rundt og sige, at vi har fuld frihed til at diskutere utopien som et historisk og tekstuelt eller generisk spørgsmål, men ikke til at komplicere det ved at betragte det politisk. (Er ordet ikke også alligevel altid blevet brugt af fremtrædende politiske skikkelser på alle fløje som et fornærmende skældsord om deres fjender?).

Ikke desto mindre er den utopiske idés aftagen et grundlæggende historisk og politisk symptom, som fortjener sin egen diagnose - om ikke en ny, mere effektiv terapi. For det første er postmodernitetens karakteristiske svækkelse af den historiske sans og forestillingen om historisk forskellighed paradoksalt forbundet med tabet af det sted hinsides al historie (eller efter dens afslutning), som vi kalder utopien. For det andet er det vanskeligt nok at forestille sig noget radikalt politisk program i dag uden den opfattelse af systemisk andethed, af et alternativt samfund, som kun ideen om utopi synes at kunne holde i live, om end nok så svagt. Det betyder selvsagt ikke, at vi - selv hvis det skulle lykkes os at genoplive utopien selv - med ét vil se konturerne af en ny og effektiv praktisk politik for globaliseringens tidsalder; men kun, at vi aldrig vil kunne nå en sådan politik uden at genoplive utopien.

\section{At forvise det onde}

Lad os da atter begynde med tekstuelle utopier selv. Her støder vi på to alternative analysemuligheder, der kan betegnes som henholdsvis den kausale og den institutionelle - eller måske endda som den diakrone og den synkrone. Den første af disse har at gøre med den utopiske verden som sådan; eller rettere og mere nøjagtigt: med den måde, hvorpå denne eller hin 'rod til alt ondt' er blevet udryddet fra denne verden. Det, enhver læser tager med fra for eksempel Thomas More, såvel som Platon, er privatejendommens afskaffelse. Dette hævdes at gøre More og Platon til kommunismens foregangsmænd. Men et nærmere blik og en undersøgelse af den teori om den menneskelige natur, som understøtter begge disse angreb på privatejendommen, viser en temmelig anderledes position: at roden til alt ondt skal findes i guld eller penge, og at det er grådighed (som et psykologisk onde), der på den ene eller anden vis må undertrykkes gennem egentligt utopiske love og forordninger med henblik på at nå til en bedre og mere human form for liv. I denne fortolkning er spørgsmålet om hierarki og egalitarisme hos More ansporet af det mere fundamentale spørgsmål om penge. Denne type utopisme har haft lange og glorværdige efterklange frem til Proudhon og Henry George og videre 
til major C.H. Douglas og de famøse falske penge [stamp-script] hos Ezra Pound. Sådanne navne antyder dog allerede, at det muligvis ikke er helt korrekt at læse undsigelsen af penge som den direkte forfader til kommunismen.

More var optaget af at udrydde de individuelle ejendomsforhold; Marx' kritik af ejendommen var anlagt på at udrydde den legale og individuelle besiddelse af de kollektive produktionsmidler; og udryddelsen af denne type privatejendom skulle føre til en situation, hvor klasserne som sådanne forsvandt, ikke blot de samfundsmæssige hierarkier og individuelle uretfærdigheder. Jeg ville gå videre og hævde, at det afgørende hos Marx er, at hans perspektiv ikke indeholder et begreb om den menneskelige natur; det er ikke essentialistisk eller psykologisk; det forudsætter ikke fundamentale drifter, lidenskaber eller syndigheder som besiddelsestrang, magtbegær, grådighed eller stolthed. Marx' diagnose er strukturel, og den er helt forenelig med nutidige eksistentielle, konstruktivistiske eller antifundamentalistiske og postmoderne overbevisninger, der udelukker forudantagelser om nogen oprindelig menneskelig natur eller essens. Hvis der har været ikke kun én menneskelig natur, men en hel række af dem, skyldes det, at den såkaldte menneskelige natur er historisk: Hvert samfund konstruerer sin egen. Og, for at parafrasere Brecht: Når nu den menneskelige natur er historisk snarere end naturlig, frembragt af mennesker snarere end indskrevet i menneskets gener eller DNA, følger det, at menneskene kan forandre den; at den ikke er en uafvendelig skæbne, men snarere et resultat af menneskelig praksis.

Marx' antihumanisme (for nu at bruge et andet ord om dette standpunkt) eller hans strukturalisme, eller endda hans konstruktivisme, rummer dermed en betragtelig landvinding i sammenligning med More. Men når vi forstår utopismen på denne vis, kan vi også få øje på en række forskellige måder, hvorpå man kan genopfinde utopien - i det mindste i denne forste betydning af afskaffelsen af denne eller hin 'rod til alt ondt', nu forstået som et strukturelt anliggende snarere end et psykologisk. Disse forskellige muligheder kan også aflæses praktisk-politisk. Hvis jeg for eksempel spørger mig selv, hvad der i dag ville være det mest vidtrækkende krav at stille til vores system - det krav, som ikke ville kunne opfyldes uden at forandre systemet til ugenkendelighed, og som med ét ville indvarsle et samfund, der adskilte sig strukturelt fra dette på enhver tænkelig måde, fra det psykologiske til det sociologiske, fra det kulturelle til det politiske - ville det være kravet om fuld beskæftigelse, universel fuld beskæftigelse hele kloden rundt. Som det bestående systems økonomiske apologeter utrætteligt har belært os om, kan kapitalismen ikke trives under fuld beskæftigelse; den kræver en reservehær af arbejdsløse for at kunne fungere og undgå inflation. Den fulde beskæftigelse som den første skruenøgle ville da blive forstærket af kravets universalitet, idet kapitalismen også behøver både en grænse og bestandig ekspansion for at opretholde sin indre dynamik. Men her bliver kravets utopisme cirkulær, for det er klart, at fuld beskæftigelse ikke blot ville forandre systemet; systemet måtte også allerede være forandret på forhånd for at opnå fuld beskæftigelse. Jeg ville ikke kalde dette for en ond cirkel, men det viser det rum, som det utopiske spring må 
foregå i, gabet mellem vores empiriske nutid og de utopiske ordninger i denne imaginære fremtid.

En sådan fremtid, imaginær eller ej, hjemsøger dog også vores nutid for at spille en diagnostisk og en kritisk-substantiel rolle. At sætte fuld beskæftigelse i forgrunden på denne måde, som det fundamentale utopiske krav, gør os i stand til at vende tilbage til de konkrete omstændigheder og situationer, at læse deres mørke punkter og patologiske dimensioner som symptomer på og virkninger af den særlige rod til alt ondt, der udpeges som arbejdsløshed. Kriminalitet, krig, forkvaklet massekultur, stoffer, vold, kedsomhed, sexisme, racisme, begær efter magt, distraktion eller nirvana - alle kan diagnosticeres som produkter af et samfund, som er ude af stand til at imødekomme alle sine borgeres produktionsevner. Her bliver den utopiske cirkularitet ikke kun en politisk vision og et politisk program, men også et redskab til kritik og diagnose.

Jeg har udfoldet dette forslag - som faktisk allerede var til stede hos More, ${ }^{2}$ og som jeg også tror på; selv om det endnu står tilbage at afgøre, hvad betegnelsen 'tro' kunne betyde i forbindelse med utopier - for at skelne det fra den anden, temmelig anderledes opfattelse af utopi, som jeg nu vil konfrontere, idet jeg vender tilbage til More (som man synes altid at måtte gøre). Hvis man nu sagde, at det virkeligt utopiske ved Mores tekst intet har at gøre med hans tanker om penge og menneskets natur, men alt at gøre med hans beretning om den utopiske indretning og det utopiske dagligliv; hvordan det fungerer politisk - øens inddeling i 54 byer, organiseringen af grupper à tredive husstande, syfogranterne, fylarkerne, senatet, transiborerne, den valgte fyrste, husstandenes funktioner (og deres middagsanretninger), ægteskab, slaver, landbrugspligter, love og så videre. Hvis dette er vores fokus og interesse, så tror jeg, vi først og fremmest må bemærke, at det indebærer en fuldkommen forandring af det perspektiv på utopien, som blev omtalt før. Jeg drister mig til at foreslå, at vores opmærksomhed i den første version af utopien, 'roden til alt ondt'-versionen, i sit væsen var eksistentiel: Som individer indgår vi i et forhold til penge og grådighed, til ejendom, og dermed føres vi til at spekulere over, hvordan livet ville arte sig uden disse sager. Dette perspektiv, tror jeg, opretholdes endda i mit eget eksempel: De fleste af os er i arbejde, men kender til frygten for arbejdsløshed og tabet af indkomst, og vi er ikke ubekendte med den psykiske nød, som den kroniske arbejdsløshed indebærer, eller med demoraliseringen, kedsomhedens morbide effekter, spildet af livskraft og fraværet af produktivitet - selv om vi er tilbøjelige til at opfatte alt dette på borgerlig, introspektiv vis.

2 Hos More er det bemærkelsesværdigt, at kristendommen og klostertraditionen bidrager til at bøje arbejdsbegrebet i retning af pligt frem for, som her, i retning af handling og produktivitet. I Utopia synes den humanistiske teksts åbenlyse epikuræisme ("alle vore handlinger, selv de dyder, der udøves gennem dem, ser i sidste ende hen mod nydelsen som deres mål og lykke") at udspringe mere af modvilje mod kristen askese (som More imidlertid også praktiserede) end af nogen synderligt positiv nydelseselskende kilde (More, IV I67). 


\section{Anonym lyksalighed}

Men idet vi orienterer os mod de utopiske politiske planer og indretninger, som jeg har nævnt, er perspektivet fuldkommen anonymt. Utopias borgere opfattes som en statistisk population; der findes ingen individer længere, for ikke at nævne nogen eksistentiel 'levet erfaring'. Når More fortæller os, at Utopias indbyggere er "sorgløse, ligevægtige, snilde og sætter pris på deres fritid", eller at de, efter Aristoteles' bestemmelser, "frem for alt holder sig til de åndelige glæder, som de værdsætter som de første og fremmeste af alle glæder”, virker dette til at forstærke det statistiske indtryk snarere end at individualisere det (More, IV I79 $\&$ i75). Hele beskrivelsen er udformet i en slags antropologisk andetheds termer, der ikke et øjeblik frister os til at se os selv for os i de andres sted, at aftegne det utopiske individ som konkret eksistentielt fortættet, selv om vi allerede kender detaljerne i hans eller hendes dagligliv (det begreb om dagliglivet, der nutildags mere eller mindre har fortrængt det om privatlivet). Man kunne indvende, at denne afpersonalisering ikke længere gælder, så snart vi når frem til utopier af William Morris' type (News from Nowhere); men måske er hans stiliserede figurer os blot nærmere i tid, fordi de stammer fra den viktorianske periode. 3 Ikke desto mindre er dette en vigtig indvending, eftersom jeg vil argumentere for, at denne effekt af anonymitet og afpersonalisering er en meget fundamental del af, hvad utopien er, og hvordan den fungerer. Den kedsommelighed eller tørhed, som er blevet tilskrevet den utopiske tekst fra More og frem, er således ikke en litterær skavank, heller ikke en alvorlig indsigelse, men en meget central styrke ved den utopiske proces i almindelighed. Den styrker det, som i dag nogle gange kaldes demokratisering eller egalitarisme, men som jeg foretrækker at kalde plebejisering: Vores afsubjektivering i den utopiske politiske proces, tabet af psykiske privilegier og åndelig privatejendom, reduktion af os alle til den psykiske sprække eller mangel, hvori vi alle består som subjekter, men som vi alle bruger store kræfter på at prøve at holde skjult for os selv.

Lad os nu vende tilbage til den skelnen, jeg har udarbejdet mellem de to utopiske perspektiver, dvs. 'roden til alt ondt'-perspektivet og det perspektiv, der knytter sig til politiske og sociale indretninger. Vi bør formentlig betragte hver af dem på to distinkte måder: som ønskeopfyldelse og som konstruktion. Begge disse tilgange indebærer tydeligt nok nydelse: ønskeopfyldelsen har nærmest per definition noget at gøre med nydelse, om end det kan indebære en lang omvej og en mangfoldig mediering gennem erstatninger. Ernst Bloch har således for længst lært os, at reklamer for patentmedicin trak på en hårdnakket kerne af længsel efter det evige liv og en forvandlet krop. Sådanne ønsker bliver endnu tydeligere, når man kommer til de forskellige utopier, hvori gamle bondedrømme om slaraffenland og stegte

3 Jeg mistænker dog afpersonaliseringen i sådanne moderne utopier for at skyldes dødeligheden og den meningsløse biologiske succession af generationer i et samfund, som hverken kender til Historiens betydning eller religionens metafysik længere. 
duer, der flyver direkte ind i munden, såvel som mere lærde fantasier om paradis og den jordiske have, befinder sig lige under overfladen.

Men konstruktionens nydelser er muligvis ikke så indlysende. Man må tænke på dem i stil med garageværkstedet, hobbymekanikerens byggesæt, Lego eller det at mure eller flikke alle mulige ting sammen. Dertil kan man også føje miniaturens særlige glæder: genskabelsen af de store ting $i$ håndarbejdsstørrelse, som man selv kan samle og afprøve, som f.eks. med hjemmekemikerens sæt, eller forandre og ombygge i uendelige variationer, næret ved nye ideer og ny viden. Disse utopiske konstruktioner - sindets modeljernbaner - udtrykker ånden i det ikkefremmedgjorte arbejde og den ikkefremmedgjorte produktion langt bedre end noget begreb om écriture eller Spiel.

\section{Den politiske viljes genrer}

Alligevel knytter der sig begrænsninger til både konstruktionsperspektivet og ønskeopfyldelsesperspektivet. Ønsker lader sig ikke altid fantasere med held - sådan opererer begrænsningerne i både fortællingen og det Reelle. Konstruktioner kan ikke altid bygges - sådan er begrænsningerne i råmaterialerne og den historiske situation, der står som det statiske og det dynamiske, de elementære love for tyngdekraft og bevægelse, for opbygningen af imaginære kollektiver. Og nogle af disse strukturelle begrænsninger kan udpeges gennem en sammenligning med beslægtede genrer og diskurstyper.

Jeg opregner fire af disse, hvortil utopien er tæt forbundet: manifestet; forfatningen; 'fyrstespejlet'; og den store profeti, der i sig rummer den modus, som kaldes satire, fordømmelsen af den faldne, syndefulde verden - som Robert C. Elliott anså for det modale modstykke til den utopiske tekst, og som er indskrevet i første bog af Mores Utopia (Elliott, Shape. Jf. også Elliott Power). ${ }^{4}$ To af de andre genrer har også sat sig spor i Utopia. Første bog beretter om samtalen mellem den rejsende Hythloday og More og hans venner, en samtale der vil munde ud i Hythlodays beskrivelse af selve Utopia $i$ anden bog (der imidlertid er skrevet tidligere end første bog). Første bog giver nemlig en hårdhændet satire over tidsalderens onder, grænsende til en profetisk skildring. 5 Den udelukker fyrstespejlet, idet Hythloday afviser hoffets muligheder og muligheden af at blive rådgiver for monarken; den undlader at udpege nogen fundamental aktør i en radikal forandring og lever dermed ikke op til Althussers forskrift for manifestet (der omfattede Machiavellis Fyrsten, skrevet på næsten samme tid som Mores Utopia) (Althusser). Og hvad

4 Det er imidlertid vigtigt at skelne mellem antiutopien (ytringen af den indædt antiutopiske og antirevolutionære ideologi, der hævder, at utopien uundgåeligt fører til undertrykkelse og diktatur, til konformitet og kedsomhed) og dystopien (som Tom Moylan kalder for 'kritisk dystopi' i sin nyttige Scraps of the Untainted Sky), der nødvendigvis er en kritik af tendenser, som gør sig gældende i kapitalismen i dag. Måske må vi føje 'oprøret mod utopien' til dette generiske system.

5 "Jeres får (...) som plejede at være så tamme og overkommelige at fodre, begynder nu efter sigende at blive så grådige og vilde, at de fortærer selve menneskene og hærger og affolker marker, huse og byer” (More, IV 67). 
angår det at skrive forfatninger - et tidsfordriv, der nåede sit højdepunkt i det revolutionære attende århundrede, men åbenbart stadig praktiseres i dag (af Giscard d'Estaing, for eksempel) - findes der vage genklange af sådanne aktiviteter $i$ anden bogs institutioner, men med noget, der synes mig at være en grundlæggende forskel. Hvis enkelte love udformes for at udelukke eller forhindre visse bestemte handlinger, performativt udpeget som forbrydelser, ville jeg vove den påstand, at forfatninger også udformes for at forhindre bestemte hændelser $i$ at indtræffe, men at disse hændelser er kollektive snarere end individuelle. Et enkelt blik på den mest succesrige af alle forfatninger, nemlig USA's forfatning, rækker da også til at vise, hvilke kollektive hændelser den er indrettet til at forhindre. Forfatninger opstår for at forebygge revolutioner som sådan og for at forhindre uorden og radikal social forandring. Det var tydeligvis en generisk kategorifejl af Jefferson at forsøge at indarbejde retten til oprør i denne slags dokument; men eftersom utopien allerede er hinsides historien, overflødiggøres alle de forbehold og forholdsregler, som forfatningsindstiftelsens genre griber til for at forhindre den. Først i den nuværende tidsalder er der dukket fortællinger op, hvori figurerne gennemfører en revolution mod selve utopien - og hvori dette forløb føles mere tilfredsstillende end overhovedet at grundlægge utopien.

Her er ikke plads til at udforske egentligt litterære analyser - diskursive, strukturelle eller semiotiske - af disse forskellige genrer og modi eller til mere konkrete meddelelser om, hvad de siger os om den, som er emnet her: den utopiske tekst. Det kan dog siges, at sådanne analyser bidrager til at bestemme det særlige forhold til det politiske som sådan, som ikke bare opretholdes af utopien som tekst, men af utopisk tænkning og utopiske impulser i almindelighed. Det er et særegent og paradoksalt forhold, som jeg allerede har antydet; utopien er enten for politisk eller ikke politisk nok. Begge bebrejdelser er udbredte og aktuelle - og minder om det ildevarslende øjeblik i Hythlodays krønike, hvor han fortæller os, at der er dødsstraf for politiske diskussioner uden for senatet, noget som heldigvis ikke er helt så almindeligt i vores verden (More, IV I25). Men grundene er klare nok: I utopien skulle politikken - ligesom historien - være overstået. Fraktionsdannelser, partier, undergrupper og særinteresser må udelukkes i Almenviljens navn. For det ene forhold, der ikke kan udfordres eller forandres, er selve systemet; og dette er i virkeligheden den grundlæggende forudsætning for alle systemer - demokratiet lige så meget som kommunismen. Man kan ikke afskaffe den parlamentariske repræsentation $i$ et parlamentarisk system; man kan ikke beslutte sig for at vende tilbage til den frie virksomhed $i$ et kommunistisk system; kooperativer kan ikke trives i et kapitalistisk markedssystem; nepotisme, arveret og nomenklaturer kan ikke tolereres i et samfund, som er forpligtet på lighed. Hvis et samfundssystem skal blive ved med at fungere, må det indeholde sine egne indbyggede immuniteter - og hvor meget desto mere gælder det samme ikke for det system, der skal gøre en ende på alle systemer? Alligevel er denne udelukkelse af politik langtfra uforenelig med de 'permanente revolutioner' i en anden type politik: det evindelige kævl og mundhuggeri, de uendelige debatter og diskussioner, der fylder Kim Stanley 
Robinsons byrådsmøder (Robinson) eller Ernest Callenbachs Survivalist Partymøder; de ustandselige ytringer af uenighed, som inspirerede Raymond Williams til at bemærke, at socialismen ville være langt vanskeligere end kapitalismen, og fik Oscar Wilde til at beklage sig over, at socialismen "tog for mange aftener". Når vi kommer til utopiens dialektik, vil vi imidlertid se, at de selv samme uenigheder, som synes at sætte More i modsætning til Callenbach og Økotopias "enorme hær af jurister”, også kan læses i et meget anderledes perspektiv (Callenbach IIo). ${ }^{6}$

\section{Intellektuel leg}

Hvordan bør vi da formulere utopiens forhold til det politiske? Jeg vil gerne foreslå følgende: at utopien dukker op i det øjeblik, hvor det politiske suspenderes. Jeg fristes nærmest til at sige: når det politiske skæres bort - eller endnu bedre, med et lån fra den lacanianske jargon for at udtrykke dens besynderlige udvendighed i forholdet til det sociale felt: i politikkens ekstimitet [extimacy]; eller endda, for at låne den figur, Derrida udleder af Abraham og Torok-analysen af Freuds ulvemenneske: i politikkens 'kryptering'. ${ }^{7}$ Men er figurer virkelig den rette måde at udtrykke den særegne autonomi, der således knytter sig til det politiske, forseglet og glemt som en cyste inden i det sociale som sådan? Måske vil det være lettere at begynde med at sige: Politikken er altid med os, og den er altid historisk, altid i færd med at forandres, udvikle sig, gå i opløsning og blive forringet. Jeg ønsker at skildre en situation, hvori de politiske institutioner synes både uforanderlige og uendeligt omformelige: Der har endnu ikke vist sig nogen aktør, som giver den mindste mulighed eller det mindste håb om en forandring af status quo, og dog kan sindet - og måske netop af den årsag - forestille sig alle slags institutionelle variationer og nysammensætninger.

Det, jeg kalder politiske institutioner, er således genstand og råmateriale for en uophørlig intellektuel leg, ligesom de hjemmemekanikersæt, jeg talte om; og alligevel er der ikke den ringeste udsigt til reform, for ikke at nævne revolution, i det virkelige liv. Og når jeg nævnte muligheden af, at denne virkelighedslammelse reelt kunne være forudsætningen for den nye, rent intellektuelle og konstruktivistiske frihed, kan paradokset forklares på denne måde: at når man nærmer sig perioder med ægte førrevolutionær gæring, når systemet virkelig synes at være ved at miste sin legitimitet, når den herskende elite er åbenlyst usikker og fuld af splittelser og tvivl på sig selv, når de folkelige krav vokser i styrke og selvtillid, så sker der også det, at disse klager og krav bliver mere præcise i deres insisteren og uopsættelighed. Vi fokuserer skarpere på meget specifikke uretmæssigheder, systemets funktions-

6 Eller jævnfør Edmund Burke om de revolutionæres sociale baggrund: "Den generelle sammensætning var af ukendte provinsadvokater, hovmestre fra lokale småjurisdiktioner, landsagførere, notarer, anstiftere og anførere af landbyens små fortrædelighedskrige. Fra det øjeblik, da jeg læste listen, så jeg tydeligt - og praktisk talt som det faktisk er hændt - alt, hvad der deraf skulle følge" (Burke).

7 Det forekommer således muligt at fundere Stephen Greenblatts velkendte fremstilling af Thomas Mores fornemmelse for det uvirkelige i netop en sådan isolation eller 'kryptering' af det politiske (jf. Greenblatt). 
svigt bliver langt mere håndgribeligt iøjnefaldende på afgørende punkter. Men i sådan et øjeblik har den utopiske forestillingsevne ikke længere frit spil: Den politiske tænkning og intelligens er trænet til meget skarpt fokuserede anliggender, de har konkret indhold, situationen kræver os i al sin historiske eneståenhed som en konfiguration; og den politiske spekulations vidtrækkende tankestrømme og digressioner viger for praktiske programmer (selv hvis de sidstnævnte er håbløst urealiserbare og 'utopiske' i den anden, affærdigende forstand). ${ }^{8}$

Er dette ikke det samme som at sige, at når det gælder politik, er utopismen allerede i sit udgangspunkt helt igennem upraktisk? Men vi kan også indkredse mulighedsbetingelserne for en sådan upraktisk spekulation på en positiv måde. Når alt kommer til alt, har størstedelen af menneskets historie jo udfoldet sig i situationer præget af udbredt afmagt og magtesløshed, hvor dette eller hint statsmagtssystem er veletableret, og oprør end ikke lader sig tænke, endsige er mulige eller forestående. Disse stræk af menneskets historie er for det meste foregået under ganske ikkeutopiske betingelser, hvori ingen af utopiens særlige forestillinger om fremtiden eller radikal forskel nogensinde når op til overfladen.

\section{Periodisering of forestillingsevnen}

For at beskrive det utopiske moment må vi således forudsætte en særegen suspension af det politiske. Det er denne suspension, denne adskillelse af det politiske - $\mathrm{i}$ al dets uforanderlige ubevægelighed - fra dagliglivet og endda fra det levedes og det eksistentielles verden, denne udvorteshed, der fungerer som stilheden før stormen, roen i orkanens øje, hvori vi kan tage os hidtil utænkelige intellektuelle friheder over for de strukturer, hvis reelle omdannelse eller afskaffelse knap synes trolig. Jeg forsøger her at karakterisere Thomas Mores situation lige før kapitalismen (i Louis Marins fremstilling) eller de absolutte monarkier og de nye nationalstaters fremvækst (i Phillip Wegners) (Marin; Wegner);9 at karakterisere selve det I8. århundrede og Rousseaus endeløse fantasier om nye forfatninger - fantasier, som synes at have opslugt ham lige så fuldstændigt som de romantiske og libidinøse fantasier, vi også forbinder med hans navn, men som dukker op i en situation, hvori den store revolution, der kun ligger få år ude i fremtiden, endnu er ganske utænkelig. Jeg tænker her også på den store utopiske produktion fra USA's populistiske og progressive epoke i slutningen af det I9. århundrede, foruden I960'ernes utopisme.

8 Perry Anderson minder mig om, at nogle af de mest ekstreme utopismer faktisk udspringer fra kernen af selve det revolutionære røre: og dog kan Winstanleys vision (i den engelske revolution) siges at danne de ideologiske retningslinjer for det, der i dag kaldes et 'intentionelt fællesskab'; mens Sades "Français, encore un effort" (La Philosophie dans le boudoir, 1795) kunne beskrives mere præcist som et modkulturelt tankeeksperiment; og Babeufs var et egentligt politisk program. Man kunne også overveje forskellene mellem de utopier, der med ophav i en såkaldt borgerlig revolution implicit undsiger denne revolutions uundgåelige grænser, og dem, der forlænger socialistiske revolutioner i det, de tror er disses egen retning og ånd (Tjajanov; Platonovs Tjevengur; endda Efremovs Andromeda)

9 Se også J.C. Davis' foruroligende og dog tankevækkende idé om, at utopier er proleptiske udtryk for den fremtidige 'totale' velfærdsstat (Davis). 
Alle disse perioder er præget af stor social grøde, men tilsyneladende uden ror, uden handling eller retning: Virkeligheden synes føjelig, men ikke systemet; og det er netop denne distance mellem det uforanderlige system og den virkelige verdens turbulente rastløshed, der synes at åbne et moment af tankemæssig og utopiskkreativ fri leg i selve bevidstheden eller i den politiske forestillingsevne. Hvis dette giver nogen form for plausibelt billede af den historiske situation, hvori utopier er mulige, står det kun tilbage at overveje, om ikke det også svarer til situationen $i$ vores egen tid.

Utopismen bygger altså på en vis distance fra de politiske institutioner, hvilket opmuntrer til en fantasiens endeløse legen med deres mulige rekonstruktioner og omstruktureringer. Men hvad er indholdet i disse fantasier? Ligesom i Freuds drømmetydning findes her de afledte udformningers eller den uendelige overdeterminations tilfredsstillelse, men også et uophørligt pres fra det ubevidste ønske eller begær. Kan vi overse det ønske uden at gå glip af alt det, der giver utopien dens vitalitet, og dets libinidøse og eksistentielle fordringer til os? Næppe. Derfor håber jeg at give et meget enkelt svar på dette spørgsmål, ét der ikke bruger udtryk som 'mere fuldendt' eller 'det almene vel', lykke, tilfredsstillelse, opfyldelse eller nogle af de andre sædvanlige slagord.

Først må man dog forklare et andet kompliceret standpunkt, der har forvirret både mine læsere og læsere af Louis Marins fine bog om emnet, der inspirerede mange af mine egne tanker. Det er, at utopien på en måde er negativ, og at den er mest autentisk utopisk, når vi ikke kan forestille os den. Dens funktion er ikke at bidrage til vores forestillinger om en bedre fremtid, men snarere at vise, at vi er helt ude af stand til at forestille os sådan en fremtid - at vi er fængslet i en ikkeutopisk nutid uden historicitet eller fremtidighed - for at afsløre den ideologiske lukning af det system, hvori vi på den ene eller anden vis er fanget og låst fast. For enhver helhjertet utopist med respekt for sig selv er dette jo et udpræget defaitistisk standpunkt at indtage, endog forsvare, og man fristes til at forklare det med nihilisme eller neurose; ånden i det er i hvert fald temmelig uamerikansk. Alligevel tror jeg, at jeg kan forsvare dets grundlæggende rimelighed ved at behandle det under to overskrifter: ideologi og frygt.

\section{Drommenes ståsted}

Hvad ideologien angår, er pointen ikke synderligt kompliceret. Den går ud fra den overbevisning, at vi alle er ideologisk situeret, lænket til en ideologisk subjektposition, bestemt af klasseforhold og klassehistorie, selv når vi forsøger at modstå dem eller flygte fra dem. Og for dem, der ikke er fortrolige med denne ideologiske perspektivisme eller klassestandpunktsteori, er det muligvis nødvendigt at tilføje, at det gælder for enhver, både venstrefløj og højrefløj, progressive og reaktionære, arbejder såvel som chefen, underklasser, marginaliserede grupper, ofre for etnisk og kønsrollebestemt undertrykkelse i lige så høj grad som de fremherskende etniske, racemæssige og kønsrollemæssige grupper. 
Denne situation har en interessant konsekvens i den aktuelle kontekst: Den betyder ikke blot, at alle utopier udspringer af bestemte klassepositioner, men at deres grundlæggende tematisering - den roden-til-alt-ondt-diagnose, som bestemmer rammerne for hver af dem - også vil afspejle et specifikt klassehistorisk standpunkt eller perspektiv. Utopisten forestiller sig ganske vist gennem sine bestræbelser at hæve sig op over alle umiddelbare bestemmelser $\mathrm{i}$ en eller anden altomfattende opløsning af ethvert muligt onde i vores eget faldne samfund og virkelighed. Sådan var for eksempel den umådelige utopiske forestillingskraft hos Charles Fourier, den samfundspolitiske spekulations Hegel, en skikkelse hvis fantasi-energi stræbte efter at indbefatte alle tænkelige karakterologiske varianter i sit ekstraordinære system. Men Fourier var småborger, og selv den fjerneste épicycle de Mercure, selv den mest rummelige Absolutte Ånd, er uundgåeligt ideologisk. Uanset hvor omfattende og klasseoverskridende eller postideologisk fortegnelsen over virkelighedens mangler og skavanker er, forbliver den forestillede opløsning nødvendigvis forbundet med dette eller hint ideologiske perspektiv.

Dette forklarer meget ved de forskellige debatter og forskelle, der har befolket den utopiske tænknings historie. For det meste kommer de i par eller som modsætninger, og jeg vil gerne rekapitulere nogle af dem - og kanske begynde med nogle af de allerede nævnte, f.eks. min egen fantasi om universel beskæftigelse. Man kan nemlig lige så vel tale for en utopi med udgangspunkt i afskaffelsen af arbejde overhovedet, en 'jobløs fremtid', hvori fraværet af arbejde er frydefuldt utopisk: Skrev Marx’ egen svigersøn ikke en bog med titlen Retten til dovenskab? Og var ikke en af I96o'ernes centrale tanker udsigten til en underbar teknologi, der ville fjerne det fremmedgjorte arbejde over hele kloden (Marcuse)? Man kan se den samme modsætning i brugen af ordene 'politik' og 'det politiske' i sammenhæng med utopien: Fremgik det ikke i det forudgående, at nogle utopister længes efter afslutningen på det politiske som sådan, mens andre svælger i udsigten til evige politiske tovtrækkerier, til ophøjelsen af kævl til at være selve essensen af et kollektivt samfundsliv?

\section{By og land}

Skal sådanne modsætninger regnes for mere end meningsforskelle, karakterologiske symptomer, eller røber de en mere grundlæggende dynamik i den utopiske proces? For få år siden - da naturen stadig fandtes, og vores samfund i deres ujævne udvikling endnu kendte til sådan noget som landområder og et kald for bønder, der ikke blot var industrielt feltarbejde i jordbrugsbranchen - var en af de mest sejlivede modsætninger i den utopiske projektion (og science fiction-skrifter) dén mellem land og by. Drejede ens fantasier sig om det at vende tilbage til landet og landsbyfællesskabet, eller var de derimod uforbederligt urbane, uvillige og ude af stand til at klare sig uden den store metropols spænding med dens menneskemasser og dens mangfoldige tilbud fra seksualitet og forbrugsgoder til kultur? Det er en modsætning, man kunne illustrere med mange navne: Heidegger over for Sartre, 
for eksempel, eller i science fiction LeGuin over for Delany. Måske indebærer dens mere samtidige form et forhold til teknologi og en tilsvarende aftagende nostalgi for naturen; eller på den anden side en lidenskabelig økologisk forpligtelse over for jordens forhistorie og en stadigt mere ynkelig stolthed over den Prometheuslignende sejr over det ikkemenneskelige. På dette punkt træder køn også ind i det utopiske billede, og det er værd at bemærke det store væld af feministiske utopier siden feminismens anden bølge i I960'erne; hvorvidt mandefællesskabernes utopier har noget tilsvarende righoldigt at tilbyde, er muligvis ikke det rette spørgsmål at stille, om end jeg vil tro, at man ville kunne søge noget sådant i den militære science fictions genopblussen og krigsfællesskabernes hierarkiske tilfredsstillelse.

Måske den mest betydningsfulde specificering af denne modsætning mellem land og by - et skift til et andet register, hvilket ikke garanterer, at talsmændene for hver af de to forbliver forpligtet på den samme position, når de skifter etage, så at sige - er modsætningen mellem planlægning og organisk vækst. I politiske og ideologiske diskussioner er denne modsætning selvsagt en gammel kending, der mindst rækker tilbage til Edmund Burkes Reflections on the Revolution in France; ja, så langt tilbage som selve denne revolution, der syntes for første gang i menneskehedens historie at hævde både den menneskelige viljes forrang frem for samfundsinstitutionerne og menneskenes magt - ét menneskes magt? et partis? en klasses? en almenviljes? - til at ændre og forme samfundet ifølge en plan, en abstrakt idé eller et ideal. Burkes tordnende fordømmelse af denne hybris hylder den magt, som tiden, den langsomme vækst og kulturen i sin etymologiske forstand må udøve, og derfor synes den at tage parti for landet mod byen. Men i dag står det måske anderledes til, og det er byen og det urbane, der vokser vildt som naturtilstanden (hvornår begyndte udtrykket 'jungle' at blive anvendt om byens 'mysterier'?), hvorimod det er naturen, der under senkapitalismen og den grønne revolution - men muligvis helt tilbage til selve den oprindelige neolitiske revolution - er blevet underkastet nøje planlægning og ingeniørkunst. I hvert fald er forestillingen om markedet som uhæmmet naturlig vækst vendt tilbage med eftertryk i den politiske tænkning, mens den venstreorienterede økologi desperat forsøger at vurdere mulighederne for et produktivt samarbejde mellem politisk handling og kloden selv. Tid og rum indgår her på lige fod: Planen er nemlig også i særlig grad en organisering af den tid, som for den burkeske konservative måtte overlades til sine egne indre tempi og rytmer, måtte lades være i sin væren, som Heidegger kunne have sagt; selv når dens helvedesmaskine - markedets temporalitet - støt fortærer det rum, som de $ø$ kologiske planlæggere ville isolere for at frigive det til dets egen spatialitets logik. Som vi har vidst siden Polanyis klassiske The Great Transformation, kræver det enorme indgreb fra styrets side at iværksætte en uhæmmet markedsfrihed. Det samme gør sig mere åbenlyst gældende for, og medgives selv af, enhver økologisk politik.

Det svagere alternativ, i det mindste i vores tid, er den pladsholder for naturen, som det frie markeds sprog helt uacceptabelt udpeger som den menneskelige natur. Økologien synes at støtte sig stadig mere hjælpeløst til denne forestillings 
magt - medmindre de økologiske tanker fremstår i apokalyptisk form eller som katastrofetænkning, global opvarmning eller udviklingen af nye vira. Alt det, der i dag synes forældet i de traditionelle utopier, søger at genoprette denne balance at styrke opfattelser af naturen, som ikke længere er overbevisende i en tidsalder, hvor plæner og landskaber og andre af naturskønhedens arketyper er blevet til systematisk fabrikerede varer (og hvor det, der tidligere stod som 'menneskets natur', har vist sig tilsvarende føjeligt og udskifteligt).

Nutidens utopiske tænkning er formet af to andre, mere karakteristiske modsætninger. Den ene er den intelligente fantasi om det, man kunne kalde en franciskansk utopi, dvs. en manglens og fattigdommens utopi. Den bygger på det indlysende forhold, at kloden bliver mindre og mindre i stand til at opretholde menneskeligt liv, for ikke at nævne andre livsformer; og på den overbevisning, at de velstående samfund som f.eks. USA vil blive nødt til at omstille sig til en anden etik, hvis ikke verden skal ende - som den for tiden synes dømt til at gøre - som et indhegnet førsteverdenssamfund omgivet af en verden af sultende fjender. I grunden er denne vurdering i sig selv en genoplivelse af den gamle modsætning mellem askese og nydelse, som har så dybe rødder i både den revolutionære og den utopiske tradition. Men selv denne modsætning bør ikke opfattes etisk eller karakterologisk. Mit standpunkt vil hverken indebære et valg mellem disse ekstremer eller en 'syntese' af dem, men snarere et stædigt negationsforhold til dem begge med afsæt i det grundlag, jeg skitserede i drøftelsen af ideologi.

Det vil nemlig være tydeligt, at hvert af disse utopiske standpunkter for sig, isoleret fra sin modpol, nødvendigvis må være dybt ideologisk. Betragtet hver for sig er disse positioner selvtilstrækkelige; deres indhold afspejler et klassestandpunkt, som per definition er ideologisk. Eller, hvis man foretrækker det: Hver af dem er nødvendigvis formidlet gennem og udtrykt ved den utopiske tænkers sociale erfaringer, der ikke kan undgå at være en klasseerfaring og at afspejle et særligt klasseperspektiv på samfundet som helhed. Dette uundgåelige klasseperspektiv indebærer heller ikke i sig selv en politisk dom: De fattiges og ubemidledes utopiske fantasier er nemlig lige så ideologiske og ladet med ressentiment som de herskendes og de privilegeredes fantasier.

Men disse utopiske modsætninger gør det muligt for os gennem negation at opfatte sandhedsmomentet $i$ hver af disse positioner. Omvendt udtrykt: Værdien af hver af disse positioner er differentiel; det ligger ikke i positionens eget substantielle indhold, men som en ideologisk kritik af dens modpol. Sandheden i naturvisionen ligger i den måde, hvorpå den afslører bydyrkelsens selvtilfredshed. Men det modsatte er også sandt. Byvisionen fremviser alt det nostalgiske og forarmede i naturdyrkelsen. En anden måde at tænke om dette på er ved at minde om, at hver af disse utopier er en fantasi og netop besidder fantasiens værdi - noget ikkerealiseret og ligefrem ikkerealiserbart i denne partielle form. Alligevel passer denne operation ikke til den stereotyp af dialektikken, hvori to modsætninger sluttelig forenes i en eller anden umulig syntese (eller i det, Greimas kalder 'den komplekse position'). Hvis denne operation er dialektisk, er her tale om en negativ dialektik, 
hvori hver position består i sin negation af den anden. Det virkelige politiske og filosofiske indhold skal findes i deres dobbelte negation. Men de to positioner må ikke udslette hinanden. Hvis de forsvandt, ville vi stå tilbage med den status quo, den aktuelle væren, som det var den utopiske fantasis funktion og værdi at have negeret, endda - som vi nu har kunnet se - negeret dobbelt.

\section{Udslettelsens terror}

Siger man hermed, at vi ikke kan danne os noget selvstændigt eller positivt billede af utopien uden at dyrke alle de mangfoldige, modstridende billeder, der sameksisterer i vores kollektive sociale underbevidsthed? Jeg vil slutte af med at se på frygten for utopien, den angst som den utopiske impuls stiller os over for. Men først vil jeg anføre det eneste svar på det afgørende spørgsmål, som forekommer mig at være ædrueligt og at have den passende højtidelighed i kraft af sin indlemmelse af selve dette ubesvarlige spørgsmåls problem: noget i stil med en nulgraders utopisk formulering. Dette eftertænksomme svar kommer forudsigeligt nok fra Adorno, og det lyder således:

"Hvis man spørger efter det emanciperede samfunds mål, får man svaret, at det er opfyldelsen af menneskelige muligheder eller livets rigdom. Lige så illegitimt det uundgåelige spørgsmål er, lige så uundgåeligt er det, at svaret bliver afvisende og triumferende [og ideologisk forældet] [...] Kun det groveste svar ville være taktfuldt: at ingen mere skal sulte. Alt andet forudsætter en tilstand, som burde bestemmes efter menneskelige behov, en menneskelig adfærd, dannet efter en model af produktionen som selvformål." (Adorno, Minima I20)

Et andet sted giver Adorno en filosofisk præcisering af den egeninteresse, som ligger i denne endelige dom, idet han hævder, at klassesamfundets ideologiske fordomme og karakterologiske deformationer udtrykker det såkaldte selvopholdelsesinstinkt, hvormed dette samfund indoktrinerer os (Adorno, Dialectic 22f). Utopien vil da være kendetegnet ved, at denne mægtige drift mod selvopholdelse falder bort, fordi den ikke længere er nødvendig.

Dette er uden tvivl en skræmmende tanke, og ikke kun på grund af den sårbarhed og de dødsfarer, den udsætter os for. Og det er denne frygt, jeg nu vil gå videre til. Dette er en diskussion, som må bevæge sig et godt stykke ud over indføringskurser i ideologianalyse. Den kræver, at vi konfronterer de mere altomfattende former for angst, der nødvendigvis venter eller overvælder enhver udsigt til fuldstændig systemforandring. Science fiction-figuren for en sådan forandring er den situation, hvor en fange eller en potentielt nødstedt advares om, at en redning kun er mulig med den omkostning, at hele personligheden - fortiden og dens erindringer, alle de mangfoldige påvirkninger og hændelser, som tilsammen har formet den nuværende personlighed - fjernes uden spor: En bevidsthed vil være det eneste, der står tilbage efter dette indgreb, men ved hvilken indsats fra for- 
nuftens eller forestillingsevnens side kan denne stadig betegnes som 'den samme' bevidsthed? Den frygt, som umiddelbart rammer os ved denne udsigt, er dermed $i$ alle henseender den samme som frygten for døden, og det er ikke uden grund, at Adorno fremmanede selvopholdelsen.

\section{Nydelser og tvang}

Noget i stil med dette er den angst, som utopien konfronterer os med, og det er lærerigt at forfølge dens paradokser et øjeblik længere. Er det ikke muligt, at utopiens resultater vil udviske alle hidtil eksisterende utopiske impulser? Som vi har set, er de nemlig alle formet og bestemt af de træk og ideologier, som vores aktuelle omstændigheder påtvinger os, og som til den tid vil være sporløst forsvundet. Men det, vi kalder vores personlighed, består af de selv samme ting - af elendighederne og misdannelserne lige så meget som nydelserne og tilfredsstillelsen. Jeg frygter, at vi ikke er i stand til at forestille os de forstnævntes forsvinden uden den fuldstændige tilintetgørelse af de sidstnævnte også, idet de to er uløseligt og kausalt sammenknyttet. Hvad angår eksistentiel erfaring, findes der intet frit valg, ingen adskillelse af hveden fra klinten. Jeg vil her give to yderligere figurlige eksempler på dette dilemma: De lærer, vi kan drage af henholdsvis afhængighed og seksualitet.

Intet samfund har nogensinde været helt så afhængigt, helt så uadskilleligt fra afhængighedens betingelse, som dette. Vores samfund har ganske vist ikke opfundet hasardspillet, men det har opfundet det tvangsmæssige forbrug. Den postmoderne kapitalisme - eller senkapitalismen - har i det mindste medført den erkendelsesmæssige gevinst at afsløre, at varens ultimative struktur er selve afhængighedens struktur (eller, om man vil: det har frembragt selve begrebet afhængighed i al dets metafysiske righoldighed). Hvad ville det indebære for den afhængige at ønske helbredelse? Vel kun denne eller hin form for ond tro eller selvbedrag - som den neurotiker (jeg tror, eksemplet kommer fra Sartre), der begynder i analyse blot for at afbryde den efter nogle få gange, hvorved han med tilfredshed kan vise, at han faktisk er uhelbredelig.

Eftersom seksualiteten tilsyneladende er mere naturlig end afhængigheden, kan et endnu mere dramatisk eksempel gives ved inddragelse af de antropologiske kommentatorer, der hævder, at seksualiteten til trods for sin allestedsnærværelse formentlig endda på grund af denne allestedsnærværelse - ikke havde ret stor betydning i stammesamfundet; at den faktisk kunne sammenlignes med den storm $i$ et glas vand, hvormed den moderne talemåde kynisk sammenligner den. Med andre ord er seksualiteten, der i sig selv er en meningsløs biologisk kendsgerning, i sådanne samfund langt mindre ladet med alle de symbolske betydninger, som vi moderne, sofistikerede mennesker tilkender den. Hvad ville det da betyde, hvis vi fra vores egen seksualiserede eksistens skulle forestille os en menneskelig seksualitet helt frigjort fra undertrykkelse og dog så fuldstændigt frataget de mangfoldige former for tilfredsstillelse, der ligger i betydningen som sådan? LeGuin dramatiserer konsekvenserne på nyttig vis fra den modsatte led gennem planeten Vinter, som 
bebos af en androgyn population, der kun differentierer sig seksuelt i bestemte tidsperioder (ligesom dyrene går i brunst). Den første besøgende på denne planet giver lærerige overvejelser:

"Den første rejsende [ambassadør], hvis en sådan sendes, må advares om, at hans stolthed vil lide et knæk, medmindre han er meget selvsikker - eller senil. En mand ønsker sin virilitet agtet, en kvinde ønsker sin femininitet værdsat, uanset hvor indirekte og subtile disse udtryk for agtelse eller værdsættelse måtte være. På Vinter vil de ikke findes. Man respekteres og vurderes udelukkende som menneske. Det er en forfærdende oplevelse." (LeGuin 95)

Meget taler for den opfattelse, at frygten for utopien er tæe knyttet til frygten for afanisis, tabet af begær: utopifolkenes kønsløshed er en konstant i den antiutopiske tradition, som det kan ses i John Boormans velkendte film Zardoz. Men meget taler også for den opfattelse, at de nævnte træk, afhængighed og seksualitet er selve emblemerne for menneskelig kultur som sådan, selve de supplementer, der definerer os som noget andet end blotte dyr: Er det ikke konkurrencementaliteten og lidenskaben eller ophidselsen, der på paradoksal vis udgør selve sindet eller ånden - i modsætning til det blot fysiske og materielle? I denne forstand er det kun alt for menneskeligt fatteligt, at vi kunne vige tilbage fra den utopi, Adorno beskrev som et samfund af 'gode dyr'. På den anden side forekommer det også muligt, at en virkelig konfrontation af utopien fordrer netop sådanne former for angst, og at deres fravær ville betyde, at vores visioner om alternative fremtider og utopiske forandringer måtte blive politisk og eksistentielt uvirksomme, rene tankeeksperimenter og åndelige spil uden nogen dybere forpligtelse.

Jeg har håbet at give udtryk for noget, som jeg endnu ikke har sagt: At utopier er ikkefiktive, selv om de også er ikkeeksisterende. Reelt kommer utopierne til os som næppe hørlige budskaber fra en fremtid, der måske aldrig bliver virkelighed. Jeg vil overlade ytringen af det budskab til indbyggerne i Marge Piercys Mattapoisettutopi - tidsrejsende fra en fremtid, som de advarer os om, muligvis aldrig vil opstå uden os selv og vores egen nutid:

"I vil måske svigte os. [...] Hver enkelt af jer vil måske ikke kunne forstå os eller kæmpe i jeres eget liv og jeres egen tid. I fra jeres tid vil måske slet ikke kæmpe [...] [Men] vi er nødt til at kæmpe for at blive til virkelighed, for at forblive virkelige, for at være den fremtid, der sker. Det er derfor, vi har opsøgt jer.” (Piercy 197f) 


\section{LITTERATURLISTE}

Adorno, Theodor. Minima Moralia. Århus: Modtryk, 1987.

Adorno, Theodor \& Max Horkheimer. Dialectic of Enlightenment. Stanford: Stanford University Press,

2002.

Althusser, Louis. Machiavelli and Us. London: Verso, I999.

Burke, Edmund. Reflections on the Revolution in France. Harmondsworth: Penguin, I976 [I790].

Callenbach, Ernest. Ecotopia. Berkeley: Bantam, I973.

Davies, James C. Utopia and the Ideal Society. Cambridge: Cambridge University Press, I98I.

Elliott, Robert C. The Power of Satire. Princeton: Princeton University Press, 1960.

Elliott, Robert C. The Shape of Utopia. Chicago: University of Chicago Press, I970.

Greenblatt, Stephen. Renaissance Self-Fashioning. Chicago: University of Chicago Press, I980.

LeGuin, Ursula K. The Left Hand of Darkness. New York: Harper \& Row, 1969.

Marcuse, Herbert. Eros og civilisationen. København: Gyldendal, I970.

Marin, Louis. Utopiques. Paris: Minuit, 1973.

More, Thomas. Complete Works. New Haven: Yale University Press, I965.

Moylan, Tom. Scraps of the Untainted Sky. Boulder: Westview Press, 2000.

Piercy, Marge. Woman on the Edge of Time. New York: Alfred A. Knopf, 1976.

Robinson, Kim Stanley. The Pacific Edge. New York: Tom Doherty, I99o.

Wegner, Phillip. Imaginary Communities: Utopia, the Nation and the Spatial Histories of Modernity.

California: University of California Press, 2002. 
DETTE MATERIALE ER OPHAVSRETSLIGT BESKYTTET OG MA IKKE VIDEREGIVES 